\title{
Substrate Utilization for Phosphatidylcholine Synthesis by Type II Pneumocytes of Neonatal Rats
}

\author{
YU-YAN YEH \\ Nutrition Department, The Pennsylvania State University, University Park, Pennsylvania 16802
}

\begin{abstract}
Type II pneumocytes isolated from neonatal rat lungs, using an isolation procedure developed for adult rats, were found to be phenotypically stable and metabolically active in culture. The cells, purified by metrizamide gradient centrifugation and differential adherence, were capable of synthesizing phospholipids from ${ }^{14} \mathrm{C}$-labeled choline, palmitate, glucose, and acetoacetate. Regardless of the ${ }^{14} \mathrm{C}$-labeled substrates used, greater than two thirds of the radioactivity incorporated into phosphatidylcholine was recovered in disaturated phosphatidylcholine, the major component of surfactant phospholipids. The incorporation of palmitate into phosphatidylcholine and other phospholipids (i.e. phosphatidyl-ethanolamine, -glycerol, -serine, and -inositol) indicates that the neonatal type II cells have the capacity to produce surfactant lipids. The neonatal cells preferentially utilized acetoacetate over glucose as a precursor of phospholipids. In the adult type II cells, glucose was incorporated into phospholipids more rapidly than acetoacetate. The rate of glucose incorporation in the neonatal cells was enhanced by exogenous insulin. The preferential utilization of acetoacetate by the neonatal type II cells is consistent with the stimulated acetoacetyl CoA synthetase pathway in the lung. The depressed glucose incorporation into phospholipid, on the other hand, may be attributed to insulin insufficiency in the neonate. (Pediatr Res 30: 55-61, 1991)
\end{abstract}

\section{Abbreviations}

PS, phosphatidylserine

PE, phosphatidylethanolamine

PG, phosphatidylglycerol

PA, phosphatidic acid

PC, phosphatidylcholine

DSPC, disaturated PC

USPC, unsaturated PC

HBSS, Hanks' balanced salt solution

Pulmonary surfactant, a lipoprotein complex, is essential for maintaining lung function by stabilizing the alveoli and preventing alveolar collapse (1). Insufficiency of surfactant is a leading cause of respiratory distress syndrome in newborns, particularly in premature infants (2). The amount of surfactant available to the alveoli depends upon its synthesis and secretion by type II pneumocytes $(3,4)$. Since the development of cell isolation

Received June 14, 1990; accepted March 11, 1991.

Correspondence: Yu-Yan Yeh, Nutrition Department, The Pennsylvania State University, University Park, PA 16802.

Supported in part by a Biomedical Research Support Grant (NIH/The Pennsylvania State University) and by the College of Health and Human Development of The Pennsylvania State University. techniques (5), type II cells have been widely used for studying the regulation of surfactant metabolism in adult and fetal animals $(6,7)$; however, little attention has been focused on newborns.

Metabolic adaptation occurs during the postnatal period when neonates are shifted from a prenatal high-carbohydrate diet to a high-fat diet (8). Accordingly, there are increases in blood concentrations of fatty acids and ketone bodies and a reduction in glucose $(9,10)$. These changes are accompanied by enhanced utilization of fatty acids and ketone bodies for energy and lipid synthesis by neonatal brain and lung $(11,12)$. It may be reasoned that surfactant phospholipid production is also adapted to the changes in substrate availability in newborns. The present study was undertaken to establish whether neonatal type II pneumocytes, isolated according to the method developed for adult cell isolation (13), are metabolically active in surfactant lipid metabolism. An attempt was also made to determine the effects of nutritional adaptation of neonatal cells on the preferential utilization of physiologic substrates for phospholipids. The results showed that neonatal type II cells were phenotypically stable in culture and capable of incorporating various substrates into surfactant phospholipids.

\section{MATERIALS AND METHODS}

Animals. Pathogen-free, timed-pregnant rats (14-16 d gestation) purchased from Harlan Sprague-Dawley Co. (Indianapolis, IN) were fed a nonpurified diet (Purina Rat Chow; RalstonPurina, St. Louis, MO) ad libitum. Newborn rats were delivered naturally and suckled by their dams until the commencement of the experiments at 6-21 d of age. Weanling rats at 24-27 d of age and adult rats (200-250 g body wt) fed ad libitum were included in the study for comparison. This research was approved by the Animal Care and Use Committee of The Pennsylvania State University. Proper care and humane treatment of animals were provided throughout the experimentation.

Cell isolation. Neonatal type II pneumocytes were isolated by a modification of the method of Mason et al. (13) developed for adult rats. Modifications were made to circumvent the difficulties in working with small rat pups and lungs. Briefly, the procedures included the following: A tracheal cannula was placed in the rat under anesthetic state for lung ventilation, lavage, and subsequent procedures. Lungs were washed via cardiopulmonary perfusion with ice cold solution I $(136 \mathrm{mM} \mathrm{NaCl}, 5.3 \mathrm{mM} \mathrm{KCl}, 5.6$ $\mathrm{mM}$ glucose, $2.6 \mathrm{mM} \mathrm{Na}_{2} \mathrm{HPO}_{4}, 10 \mathrm{mM} \mathrm{N}$-2-hydroxyethylpiperazine- $N^{\prime}$-2-ethanesulfonic acid buffer, $\mathrm{pH}$ 7.4) to remove blood. After lavage with solution II (solution I containing 1.9 $\mathrm{mM} \mathrm{CaCl}$ and $1.3 \mathrm{mM} \mathrm{MgSO}_{4}$ ), the lungs were instillated with fluorocarbon-albumin emulsion (fluorocarbon: 1\% BSA in solution II; $1: 15 ; \mathrm{vol} / \mathrm{vol}$ ) and incubated for further removal of macrophages. Trypsin solution $(0.3 \%$ trypsin and $0.003 \%$ DNase in solution II) in combination with mechanical chopping (McIlwain Tissue Chopper; Brinkmann Instruments, Co., Westbury, 
NY) were then used to dissociate cells from the lung tissues. After the enzymatic digestion, the residual trypsin was neutralized with a soybean trypsin inhibitor solution $(0.1 \%$ of the inhibitor and $0.003 \%$ DNase in solution II).

Type II cells were purified by sequential filtration through cotton gauze and nylon meshes and by discontinued metrizamide gradient ( 1.04 and $1.095 \mathrm{~g} / \mathrm{mL}$ ) centrifugation. Type II cells were collected from the interphase between the two gradients. For further purification by differential adherence, the cells were resuspended in C-MEM (i.e. minimal essential medium with Earle's salts supplemented with $10 \%$ FCS, $100 \mathrm{U}$ penicillin $/ \mathrm{mL}$, and $100 \mu \mathrm{g}$ of streptomycin $/ \mathrm{mL}$ ) and incubated in culture flasks $\left(25 \mathrm{~cm}^{2}\right)$ at $37^{\circ} \mathrm{C}$ in an atmosphere of $5 \% \mathrm{CO}_{2}$ and $95 \%$ air. Two $\mathrm{h}$ after the incubation, nonadherent cells were transferred to new flasks and incubated for 20-24 h. At the end of the incubation, the medium containing nonadherent cells was discarded. Type II cells adhering to the flasks were used for morphologic, biochemical, and metabolic studies.

Identification and characterization. Type II cells were identified under light microscope by the presence of cytoplasmic blue granules stained with the modified Papanicolaou stain (5). For transmission electron microscopy, the cells were resuspended in a given volume of HBSS. An equal volume of $4 \%$ glutaraldehyde in $0.1 \mathrm{M}$ sodium cacodylate, $\mathrm{pH} 7.4$, was added to the cell suspension, and the cells were spun down. After $2 \mathrm{~h}$ at room temperature in the $2 \%$ glutaraldehyde buffer, the cells were postfixed in $1 \%$ osmium tetroxide, $0.1 \mathrm{M}$ cacodylate buffer for $2 \mathrm{~h}$ at $0^{\circ} \mathrm{C}$. The sample was then dehydrated, first through a graded series of ethanol solutions and then by propylene oxide. It was next embedded in Spurr resin and cured in the oven overnight at $70^{\circ} \mathrm{C}$. Eighty-five-nm-thick sections were then cut on a Sorvall 6000 ultramicrotome and viewed at $80 \mathrm{kV}$ using a Philips 301 transmission electron microscope.

Metabolic studies. To measure the rate of substrate incorporation into phospholipids, type II cells adhering to flasks after 20-24 h of incubation were rinsed twice with $2 \mathrm{~mL}$ of incubation medium consisting of $125 \mathrm{mM} \mathrm{NaCl}, 5 \mathrm{mM} \mathrm{KCl}, 2.5 \mathrm{mM} \mathrm{CaCl}_{2}$, $2.5 \mathrm{mM} \mathrm{Na}_{2} \mathrm{HPO}_{4}, 1.2 \mathrm{mM} \mathrm{MgSO}_{4}, 12 \mathrm{mM} \mathrm{N}$-2-hydroxyethylpiperazine- $N^{\prime}$-2-ethanesulfonic acid, $\mathrm{pH} 7.4,100 \mathrm{U}$ penicillin/ $\mathrm{mL}$ and $100 \mu \mathrm{g}$ streptomycin/mL (14). The cells were incubated at $37^{\circ} \mathrm{C}$ under an atmosphere of $5 \% \mathrm{CO}_{2}$ and $95 \%$ air in $2 \mathrm{~mL}$ of the fresh incubation medium containing either [Me- $\left.{ }^{14} \mathrm{C}\right] \mathrm{cho}-$ line (sp act, $10 \mu \mathrm{Ci} / \mu \mathrm{mol}$ ), $0.025 \mathrm{mM}$ plus glucose, $5.6 \mathrm{mM}$ and palmitate, $0.2 \mathrm{mM}$; or $\left[1-{ }^{14} \mathrm{C}\right]$ palmitate (sp act, $10 \mu \mathrm{Ci} / \mu \mathrm{mol}$ ), $0.2 \mathrm{mM}$ plus glucose, $5.6 \mathrm{mM}$ and choline, $0.025 \mathrm{mM}$; or [U$\left.{ }^{14} \mathrm{C}\right]$ glucose (sp act, $\left.4 \mu \mathrm{Ci} / \mu \mathrm{mol}\right), 5.6 \mathrm{mM}$ and choline, 0.025 $\mathrm{mM}$; or $\left[3-{ }^{14} \mathrm{C}\right]$ acetoacetate (sp act, $4 \mu \mathrm{Ci} / \mu \mathrm{mol}$ ), $2 \mathrm{mM}$ plus glucose, $5.6 \mathrm{mM}$ and choline, $0.025 \mathrm{mM}$. Whenever palmitate was present, BSA (fraction V, fatty-acid free) was added to obtain a palmitate/albumin molar ratio of 5.6:1. After incubation for 4 $\mathrm{h}$, or as otherwise indicated in the figures, the medium was aspirated and the cells washed twice with $2 \mathrm{~mL}$ of HBSS. The cells were then harvested with $1.2 \mathrm{~mL}$ of HBSS containing $0.05 \%$ trypsin and $0.02 \%$ EDTA. An aliquot of the cell suspension was taken for cell count with a hemocytometer. In an experiment to compare the utilization of substrates by adults and neonates, the same concentrations of glucose $(5.6 \mathrm{mM})$ and acetoacetate $(2$ $\mathrm{mM}$ ) were tested. The glucose concentration was within the range $(80-140 \mathrm{mg} / \mathrm{dl}$ equivalent to $4.4-7.7 \mathrm{mM})$ found in the circulation of neonatal and adult rats (9). The 2-mM concentration of acetoacetate was chosen because plasma levels of total ketone bondies (acetoacetate and $\beta$-hydroxybutynate) reached $1.2-1.6 \mathrm{mM}$ in neonates suckled by their dams compared with adult levels of 0.3 and $1.2 \mathrm{mM}$ obtained under fed and fasting conditions, respectively (9). Therefore, not only were these substrate concentrations close to physiologic ranges but they also provided an excess of unlabeled acetoacetate and glucose to minimize the potential dilution of ${ }^{14} \mathrm{C}$-labeled precursor sp act by intracellular substrates.

For lipid analysis, the remaining cells were transferred to a tube containing $20 \mathrm{~mL}$ of chloroform:methanol (2:1, vol/vol). An aliquot of lipid extract from adult rat lung was added as a carrier for the extraction of ${ }^{14} \mathrm{C}$-labeled lipids, according to the method of Folch et al. (15). Phospholipids, DSPC, and USPC were separated by thin-layer chromatographic procedures of Gilfillan et al. (16), except that a chloroform:methanol: $\mathrm{NH}_{4} \mathrm{OH}$ $(80: 28: 6, \mathrm{vol} / \mathrm{vol} / \mathrm{vol})$ mixture was used as the solvent in the second dimensional system. Lipids were visualized with iodine vapor and identified by comparison with known standards. Each lipid fraction was scraped and its radioactivity determined by liquid scintillation spectrometry (model LS 8100; Beckman, Fullerton, CA) as described previously (17). For determination of the lipid profile of isolated type II cells in other experiments, phospholipids were isolated by the same procedure. Silica gel containing individual phospholipids was used directly for measuring phosphorus (18).

Metabolite assay. To measure endogenous concentrations of acetoacetate and glucose, type II cells were plated in large flasks $\left(75 \mathrm{~cm}^{2}\right)$ under the same conditions used for metabolic studies. At the end of $24 \mathrm{~h}$ incubation, attached cells were harvested and treated with $40 \%$ (wt/vol) perchloric acid. The cell suspension was centrifuged at $1500 \times g$ for $10 \mathrm{~min}$ at $4^{\circ} \mathrm{C}$. The supernatant containing acetoacetate and glucose was adjusted with $40 \%$ (wt/ vol) $\mathrm{KOH}$ to $\mathrm{pH} 7.0$ (9). Acetoacetate and glucose were measured enzymatically as previously described (9).

Chemicals and media. $\left[\mathrm{Me}-{ }^{14} \mathrm{C}\right]$ choline, $\left[1-{ }^{14} \mathrm{C}\right]$ palmitate, [U$\left.{ }^{14} \mathrm{C}\right]$ glucose, and ethyl $\left[3-{ }^{14} \mathrm{C}\right]$ acetoacetate were purchased from New England Nuclear (Boston, MA). Ethyl $\left[3-{ }^{14} \mathrm{C}\right]$ acetoacetate was converted to $\left[3-{ }^{14} \mathrm{C}\right]$ acetoacetate according to the procedure described previously (19). Tissue culture media, FCS, and antibiotics were obtained from GIBCO Labs (Grand Island, NY). Organic solvents, all reagent grade, were the products of Fisher Scientific (Pittsburgh, PA). All other chemicals were from Sigma Chemical Co. (St. Louis, MO).

Statistical analysis. Data are presented as means \pm SEM. The comparisons of different treatments of the cells in culture were made by one-way analysis of variance. When a statistical significance was indicated by the analysis of variance, Duncan's multiple range test was used to identify the significant difference between groups.

\section{RESULTS}

Isolation and characterization. The cells that adhered to the flask at $24 \mathrm{~h}$ after incubation in C-MEM were examined for purity. The cells were identified as type II pneumocytes by the presence of lamellar inclusion bodies using the electron microscope (Fig. 1). The isolated type II cells had well-preserved subcellular organelles, e.g. mitochondria, microsomes, and rough endoplasmic reticulum. Type II cells accounted for $83.0 \pm 1.5$ and $86.5 \pm 4.2 \%$ of the isolated cell population as identified by electron microscopy and the differential cell counts of Papanicolaou-stained cells, respectively. The major contaminants were lymphocytes and macrophages.

The cell yields obtained at different stages of isolation are shown in Table 1 . The numbers of type II cells obtained at $24 \mathrm{~h}$ after differential adherence in culture ranged from 1.9-2.7 $\times 10^{6}$ cells per two neonatal rats, representing $12-17 \%$ of the total cells isolated after metrizamide gradient centrifugation. A higher yield, i.e. $3.6 \times 10^{6}$ cells, was obtained per adult rat. The neonatal type II cells were found to be approximately $95 \%$ viable by trypan blue exclusion test. During the course of isolation, four to eight neonatal rats or four adult rats could be processed without difficulty. In some experiments, it was found that replacement of trypsin by elastase, according to the procedure of Dobbs et al. (20), did not improve the cell yield from neonatal lungs (data not shown).

The analysis of lipids revealed that of total phospholipids contained in the neonatal type II cells, PC was the predominant 


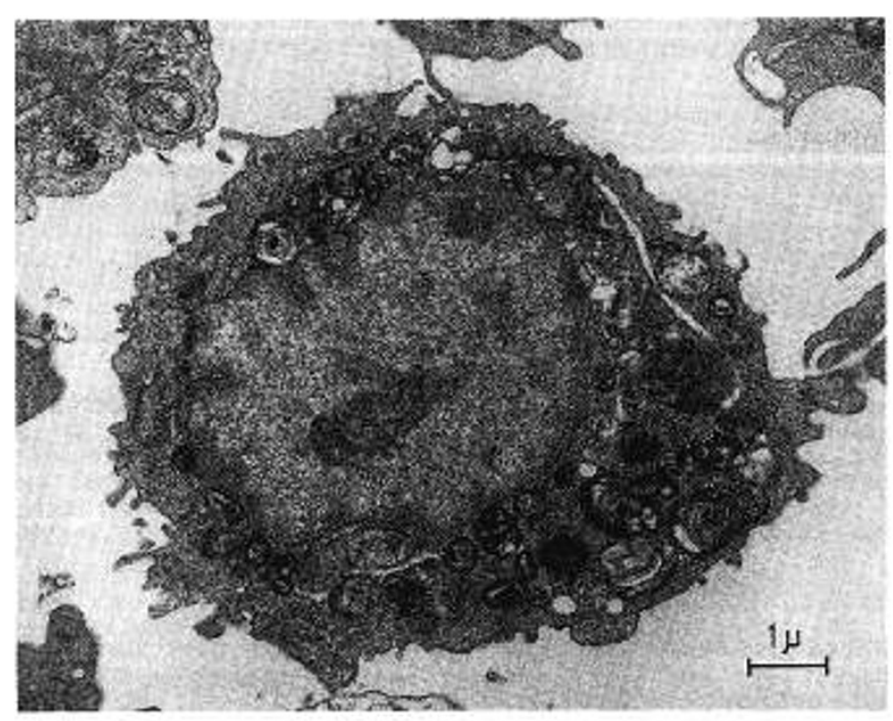

Fig. 1. Electron micrograph of a type II pneumocyte isolated from 8$\mathrm{d}$-old rats and cultured for $24 \mathrm{~h}$. The insert bar represents $1 \mu \mathrm{m}$.

Table 1. Yield of alveolar type II cells isolated from neonatal and adult rat lungs*

\begin{tabular}{ccll}
\hline $\begin{array}{c}\text { Age } \\
(\mathrm{d})\end{array}$ & $\begin{array}{c}\text { Cells isolated after } \\
\text { gradient }\left(\times 10^{6}\right)\end{array}$ & $\begin{array}{c}\text { Cells adhered } \\
\text { after } 24 \mathrm{~h} \text { in } \\
\text { culture }\left(\times 10^{6}\right)\end{array}$ & $\begin{array}{c}\% \text { Cells } \\
\text { adhered }\end{array}$ \\
\hline $6-10$ & $14.62 \pm 1.66(28)$ & $1.94 \pm 0.22$ & $11.7 \pm 0.7$ \\
$14-21$ & $18.23 \pm 1.00(31) \dagger$ & $2.70 \pm 0.28 \dagger$ & $17.0 \pm 1.6 \dagger$ \\
$24-27$ & $15.20 \pm 1.40(12) \ddagger$ & $2.62 \pm 0.82$ & $15.1 \pm 3.1$ \\
Adult & $34.84 \pm 5.61(11) \dagger \ddagger \S$ & $3.64 \pm 0.40 \dagger \ddagger$ & $10.5 \pm 1.0 \ddagger \S$ \\
\hline
\end{tabular}

* Values are means \pm SEM for numbers of isolation indicated in parentheses. For each isolation, lungs from two neonatal rats were pooled and one from an adult rat $(200-250 \mathrm{~g}$ body wt) was used.

$\dagger$ Statistically significant difference at $p<0.05$ from the value observed for 6- to 10-d-old group.

$¥$ Statistically significant difference at $p<0.05$ from the value observed for 14- to 21-d-old group.

$\S$ Statistically significant difference at $p<0.05$ from the value observed for 24- to 27-d-old group.

Table 2. Phospholipid composition of type II pneumocytes of neonatal rats*

\begin{tabular}{lc}
\hline \multicolumn{1}{c}{ Phospholipid } & $\begin{array}{c}\text { \% Total } \\
\text { phospholipid }\end{array}$ \\
\hline Lysophosphatidylcholine & $2.1 \pm 0.4$ \\
Sphingomyelin & $2.7 \pm 0.2$ \\
PC & $66.8 \pm 2.4$ \\
DSPC & $46.7 \pm 2.0$ \\
Phosphatidylinositol & $3.4 \pm 0.2$ \\
PS & $2.1 \pm 0.3$ \\
PE & $11.7 \pm 0.6$ \\
PG & $10.4 \pm 1.3$ \\
Cardiolipin & $0.8 \pm 0.08$ \\
\hline
\end{tabular}

* Values are the means \pm SEM for six isolations obtained in different experiments. Each sample contained 1.9-2.2 $\times 10^{6}$ cells from 6- to 8-dold rats. The percentage of distribution into individual lipids was calculated on the basis of total phospholipid phosphorus $\left(0.117 \pm 0.09 \mu \mathrm{g} / 10^{6}\right.$ cells) obtained for the six samples.

component accounting for $67 \%$, followed by PE (12\%) and PG (10\%) (Table 2). DSPC accounted for $70 \%$ of the total PC.

Substrate incorporation into phospholipids. To determine whether the cultured type II cells retain their major metabolic functions, the capacities to incorporate various ${ }^{14} \mathrm{C}$-labeled substrates into phospholipids were measured. Neonatal type II cells

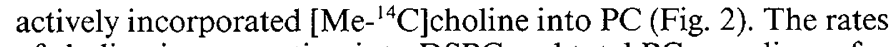
of choline incorporation into DSPC and total PC were linear for up to $6 \mathrm{~h}$ after the initial time lag observed during the incubation. Of the total radioactivity incoporated into PC, 76-78\% were accounted for by DSPC. Constant rates of ${ }^{14} \mathrm{C}$-choline incorporation into DSPC ( $3.1-3.48 \mathrm{nmol} / 4 \mathrm{~h} / 10^{6}$ cells) and USPC $(0.93-$ $1.09 \mathrm{nmol} / 4 \mathrm{~h} / 10^{6}$ cells) were obtained with $0.35,0.52$, and 0.7 $\times 10^{6}$ cells per incubation.

The utilization of palmitate was then investigated. As shown in Figure 3, the rates of $\left[1-{ }^{14} \mathrm{C}\right]$ palmitate incorporation into PC and DSPC increased linearly with increasing time of incubation

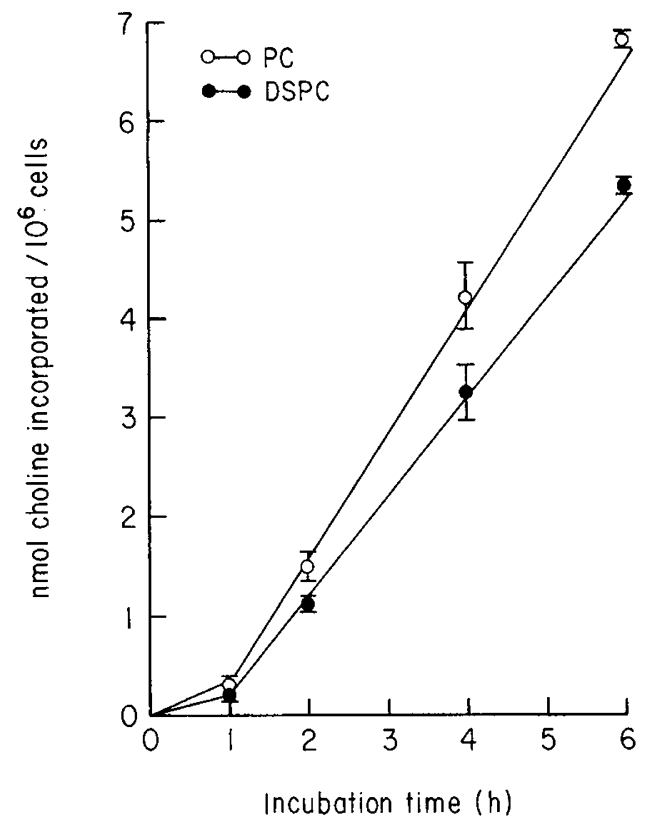

Fig. 2. Incorporation of $\left[\mathrm{Me}^{-14} \mathrm{C}\right]$ choline into $\mathrm{PC}$. Values are means \pm SEM for three experiments calculated from an average value of triplicate samples included in each experiment. A total of $0.3-0.8 \times 10^{6}$ cells/flask isolated from 6- to 8-d-old rats were used.

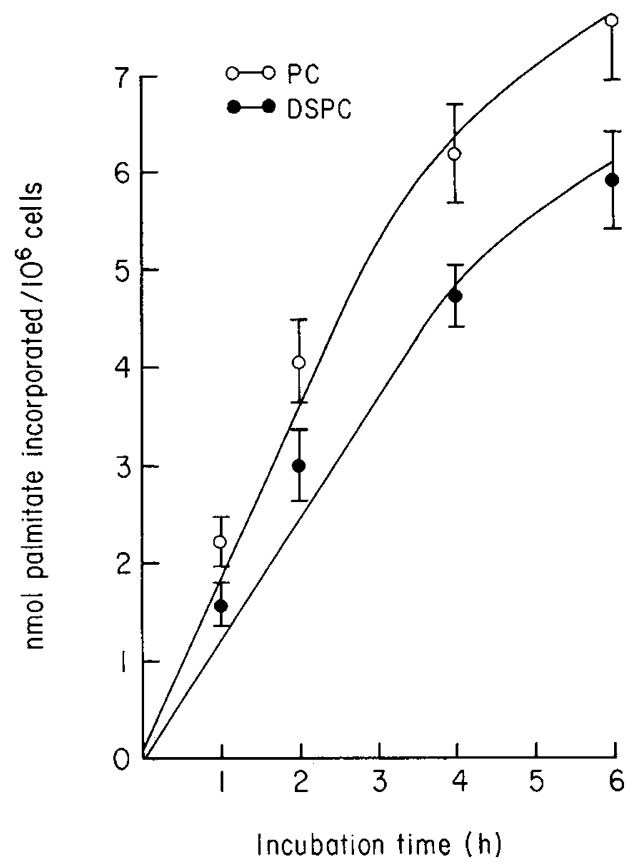

Fig. 3. Incorporation of $\left[\mathrm{II}^{-14} \mathrm{C}\right]$ palmitate into $\mathrm{PC}$. Values are means \pm SEM for three experiments calculated from an average value of triplicate samples included in each experiment. A total of $0.4-0.8 \times 10^{6}$ cells/flask isolated from 7- to 8-d-old rats were used. 
up to $4 \mathrm{~h} .{ }^{14} \mathrm{C}$-radioactivity recovered in DSPC represented 72 $76 \%$ of that found in total PC during different incubation periods. Of the total radioactivity incorporated into phospholipids, PC accounted for $76.6 \%$, PG 7.6\%, PE 6.4\%, PS 2.6\%, PA $2.5 \%$, phosphatidylinositol $2.3 \%$, sphingomyelin $1.5 \%$, and lysophosphatidylcholine $0.5 \%$.

In the next series of experiments, the utilization of glucose by type II cells was studied under different conditions in culture. As shown in Table 3, [U $\left.{ }^{14} \mathrm{C}\right]$ glucose was readily incorporated into the phospholipids by neonatal type II cells cultured for $24 \mathrm{~h}$. Of the total radioactivity found in phospholipids, DSPC and USPC together amounted to more than two thirds, with the remaining distributed to PE, PG, and others. To establish the metabolic stability of type II cells, the rates of $\left[\mathrm{U}^{14} \mathrm{C}\right]$ glucose utilization were compared for cells maintained in culture for up to $4 \mathrm{~d}$ (Table 3). The rates of glucose incorporation into phospholipids remained constant throughout the first $3 \mathrm{~d}$ in culture. An additional day in culture resulted in a decreased rate of the incorporation. There was no change in percentage of distribution of glucose radioactivity into USPC and PA throughout $4 \mathrm{~d}$ of culture. A slight reduction in percentage of distribution into DSPC was noted on $\mathrm{d} 3$ and 4 , and the percentage of distribution into PE appeared to be higher on $\mathrm{d} 3$ than on other days. The percentage of distribution into PG was the lowest on $\mathrm{d} 3$.

Table 4 shows the results of the experiments in which $\left[\mathrm{U}_{-}{ }^{14} \mathrm{C}\right]$ glucose utilization in the presence of exogenous porcine insulin $\left(10^{-9}\right.$ to $\left.10^{-7} \mathrm{M}\right)$ was investigated. The rate of $\left[\mathrm{U}^{-14} \mathrm{C}\right] \mathrm{glucose}$ incorporation into PC, PE, and PG was increased by insulin in a dose-dependent manner from $10^{-9}$ to $10^{-8} \mathrm{M}$. There was no further increase in the rate at $10^{-7} \mathrm{M}$. The rates of [U $\left.{ }^{14} \mathrm{C}\right]$ glucose incorporation into total phospholipids were higher in insulinsupplemented than nonsupplemented cells, primarily because of the increased radioactivities in PC, PS, PE, and PG. The data clearly indicate that type II cells derived from neonatal rats are responsive to insulin.

Preferential utilization of physiologic substrates for phospholipid production by neonatal and adult type II cells was determined. The results (Table 5) demonstrated that the rate of incorporation of $\left[\mathrm{U}-{ }^{14} \mathrm{C}\right]$ glucose into total phospholipids in neonates equaled only one third of that in adults (i.e. 3.4 versus 9.5 $\mathrm{nmol}$ of glucose, or 10.2 versus $28.4 \mathrm{nmol}$ of acetyl units incorporated $/ 4 \mathrm{~h} / 10^{6}$ cells). The rate noted for the neonates was consistent with lower radioactivities recovered in individual phospholipids except sphingomyelin, PS, and PA. Conversely, the rates of $\left[3-{ }^{14} \mathrm{C}\right]$ acetoacetate incorporation into DSPC and USPC in neonates were two times of that in adults (Table 5). A greater amount of ${ }^{14} \mathrm{C}$-acetoacetate incorporation into other phospholipids were also observed for neonates. The rates of acetoacetate incorporation into total phospholipids were 19.1 and $9.6 \mathrm{nmol}$ of acetyl units per $4 \mathrm{~h} / 10^{6}$ cells for neonatal and adult rats, respectively.

To determine whether endogenous substrate pools significantly diluted the sp act of ${ }^{14} \mathrm{C}$-labeled acetoacetate and glucose presented in the incubation medium, cellular contents of the metabolites were measured in the cultured hepatocytes maintained under the same conditions used in the preceding experiment (Table 5). The results showed that cells of the neonatal rats contained $29 \pm 3 \mathrm{nmol}$ of acetoacetate and $15 \pm 1 \mathrm{nmol}$ of glucose per $1 \times 10^{6}$ compared with the corresponding values of $10 \pm 1$ and $27 \pm 1 \mathrm{nmol}$ per $1 \times 10^{6}$ cells for the adult counterparts. In the experiment presented in Table 5, 0.3-0.7 $\times$ $10^{6}$ cells of the neonates and $0.8-1.0 \times 10^{6}$ cells of the adults were incubated in $2 \mathrm{~mL}$ of the medium containing $2 \mathrm{mM}$ acetoacetate or $5.6 \mathrm{mM}$ glucose. From these data it was estimated that endogenous acetoacetate could contribute $0.22-0.51 \%$ and glucose $0.04-0.09 \%$ to the neonatal pools compared with 0.20 $0.25 \%$ of acetoacetate and $0.19-0.24 \%$ of glucose to the adult pools. These data suggest that the exclusion of the endogenous sources from calculation in the preceding experiment (Table 5) had little or no effect on measuring the rates of $\left[\mathrm{U}-{ }^{14} \mathrm{C}\right] \mathrm{glucose}$ and $\left[3-{ }^{14} \mathrm{C}\right]$ acetoacetate incorporation into phospholipids.

\section{DISCUSSION}

Alveolar type II cells were isolated from neonatal rats (6-21 d of age) by modifications of the method developed for the isolation from adult rats (13). The modified procedure yielded $1-2 \times 10^{6}$ cells per pup with a purity of $83-87 \%$ compared with a range of $1-3 \times 10^{6}$ cells per pup and purity of $85-95 \%$ previously reported by others for 1 -wk-old rats $(21,22)$. The reasons for the slightly lower purity observed in the present study are not clear but may be related to a number of factors such as the original number of cells plated, available surface area of culture flask, adhesive properties of the flask, age of animals, concentrations of trypsin used for cell isolation, and identification of type II cells on the basis of the appearance of lamellar body, which is dependent on the maturity of the cells (22-24). Nevertheless, using the modified procedure it was possible to process four to eight rat pups in a single isolation to provide sufficient numbers of cells for subsequent metabolic studies.

The neonatal type II cells maintained in culture were metabolically active in incorporating choline, palmitate, glucose, and acetoacetate into phospholipids. The data, however, do not allow one to assess the quantitative contribution of individual substrates to the overall synthesis of phospholipids because substrate pool sizes were not determined for all the substrates tested. It is clear, however, that regardless of the labeled substrates used,

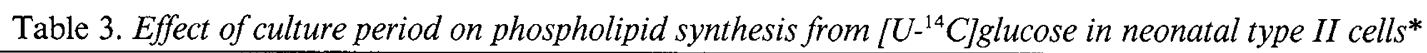

\begin{tabular}{lcccc}
\hline & \multicolumn{4}{c}{ Day in culture } \\
\cline { 2 - 5 } & PL & \multicolumn{4}{c}{2} & 3 & 4 \\
\hline LPC & $2.4 \pm 0.4$ & $2.3 \pm 0.2$ & $3.3 \pm 1.3$ & $3.5 \pm 0.3 \dagger \ddagger$ \\
SP & $2.1 \pm 0.5$ & $2.0 \pm 0.1$ & $1.6 \pm 0.2 \ddagger$ & $2.2 \pm 0.3 \S$ \\
PI & $2.5 \pm 0.1$ & $2.7 \pm 0.2$ & $3.2 \pm 0.3 \dagger$ & $2.8 \pm 0.9$ \\
PS & $1.3 \pm 0.1$ & $1.4 \pm 0.2$ & $1.9 \pm 0.2 \dagger \ddagger$ & $2.1 \pm 0.1 \dagger \ddagger$ \\
PE & $11.2 \pm 0.7$ & $1.6 \pm 2.4$ & $16.8 \pm 0.7 \dagger \ddagger$ & $12.4 \pm 2.3 \S$ \\
PG & $7.2 \pm 0.7$ & $5.1 \pm 1.2$ & $2.6 \pm 0.5 \dagger \ddagger$ & $3.8 \pm 0.2 \dagger \S$ \\
PA & $0.2 \pm 0.3$ & $0.3 \pm 0.1$ & $0.4 \pm 0.2$ & $0.4 \pm 0.2$ \\
DSPC & $47.8 \pm 2.8$ & $51.4 \pm 1.3$ & $47.7 \pm 1.5 \ddagger$ & $45.9 \pm 2.5 \ddagger \S$ \\
TSPC & $25.1 \pm 3.0$ & $22.8 \pm 1.4$ & $22.2 \pm 2.3$ & $24.3 \pm 1.3$ \\
\hline
\end{tabular}

\footnotetext{
$*$ Values are \% of total PL radioactivity (mean \pm SEM) for three experiments with triplicate flasks per experiment. In these experiments, $0.3-0.6$ $\times 10^{6}$ cells from 9-d-old rats were used per flask. LPC, lysophosphatidylcholine; SP, sphingomyelin; PI, phosphatidylinositol; and PL, phospholipid. $\dagger$ Indicates a statistically significant difference at $p<0.05$ from the value of cells in culture for $1 \mathrm{~d}$. $¥$ Indicates a statistically significant difference at $p<0.05$ from the value of cells in culture for $2 \mathrm{~d}$. $\S$ Indicates a statistically significant difference at $p<0.05$ from the value of cells in culture for $3 \mathrm{~d}$.
} 
Table 4. Effect of insulin on the incorporation of $\left[\mathrm{U}^{14} \mathrm{C}\right]$ glucose into phospholipids in neonatal type II cells*

\begin{tabular}{lllll}
\hline & \multicolumn{4}{c}{ Insulin $(\mathrm{M})$} \\
\cline { 2 - 5 } PL & \multicolumn{1}{c}{0} & \multicolumn{1}{c}{$10^{-9}$} & $10^{-8}$ & $10^{-7}$ \\
\hline LPC & $0.15 \pm 0.02$ & $0.14 \pm 0.03$ & $0.06 \pm 0.01 \dagger \ddagger$ & $0.13 \pm 0.02 \S$ \\
SP & $0.01 \pm 0.002$ & $0.02 \pm 0.01$ & $0.04 \pm 0.01 \dagger \ddagger$ & $0.03 \pm 0.01 \ddagger$ \\
PC & $2.46 \pm 0.10$ & $2.82 \pm 0.08 \dagger$ & $3.62 \pm 0.17 \dagger \ddagger$ & $3.74 \pm 0.12 \dagger \ddagger$ \\
PI & $0.05 \pm 0.01$ & $0.06 \pm 0.01$ & $0.09 \pm 0.01 \dagger \ddagger$ & $0.09 \pm 0.01 \dagger \ddagger$ \\
PS & $0.01 \pm 0.002$ & $0.02 \pm 0.002 \dagger$ & $0.03 \pm 0.002 \dagger \ddagger$ & $0.03 \pm 0.01 \dagger$ \\
PE & $0.55 \pm 0.03$ & $0.62 \pm 0.03 \dagger$ & $0.75 \pm 0.02 \dagger \ddagger$ & $0.84 \pm 0.07 \dagger \ddagger$ \\
PG & $0.08 \pm 0.01$ & $0.13 \pm 0.01 \dagger$ & $0.22 \pm 0.03 \dagger \ddagger$ & $0.15 \pm 0.03+\S$ \\
CL & $0.12 \pm 0.03$ & $0.14 \pm 0.07$ & $0.11 \pm 0.02$ & $0.07 \pm 0.01 \dagger \S$ \\
Total PL & $3.44 \pm 0.12$ & $4.00 \pm 0.14 \dagger$ & $4.91 \pm 0.20 \dagger \ddagger$ & $5.07 \pm 0.25 \dagger \ddagger$ \\
\hline
\end{tabular}

$*$ Values are nmol glucose incorporated $/ 4 \mathrm{~h} / 10^{6}$ cells (mean $\pm \mathrm{SEM}$ ) for three experiments with triplicate flasks per experiment. In these experiments, $0.3-0.5 \times 10^{6}$ cells from 16-d-old rats were used per flask. LPC, lysophosphatidylcholine; SP, sphingomyelin; PI, phosphatidylinositol; PL, phospholipid; CL, cardiolipin.

$\dagger$ Indicates a statistically significant difference at $p<0.05$ from the value obtained in the absence of insulin.

$\$$ Indicates a statistically significant difference at $p<0.05$ from the value obtained in the presence of $10^{-9} \mathrm{M}$ insulin.

$\S$ Indicates a statistically significant difference at $p<0.05$ from the value obtained in the presence of $10^{-8} \mathrm{M}$ insulin.

Table 5. [U- $\left.{ }^{14} \mathrm{C}\right]$ Glucose and $\left[3-{ }^{14} \mathrm{C}\right]$ acetoacetate incorporation into phospholipids in neonatal and adult type II cells*

\begin{tabular}{|c|c|c|c|c|}
\hline \multirow[b]{2}{*}{ PL } & \multicolumn{2}{|c|}{$\left[\mathrm{U}-{ }^{14} \mathrm{C}\right] \mathrm{glucose}$} & \multicolumn{2}{|c|}{$\left[3-{ }^{14} \mathrm{C}\right]$ acetoacetate } \\
\hline & Neonate & Adult & Neonate & Adult \\
\hline LPC & $0.06 \pm 0.01$ & $0.12 \pm 0.02 \dagger$ & $0.26 \pm 0.03 \dagger \ddagger$ & $0.07 \pm 0.004 \ddagger \S$ \\
\hline $\mathrm{SP}$ & $0.04 \pm 0.01$ & $0.05 \pm 0.02$ & $0.29 \pm 0.02 \dagger \ddagger$ & $0.13 \pm 0.01 \dagger \ddagger \S$ \\
\hline PI & $0.02 \pm 0.002$ & $0.08 \pm 0.01 \dagger$ & $0.22 \pm 0.02 \dagger \ddagger$ & $0.11 \pm 0.02 \dagger \S$ \\
\hline PS & $0.04 \pm 0.004$ & $0.06 \pm 0.002$ & $0.32 \pm 0.01 \dagger \ddagger$ & $0.20 \pm 0.04 \dagger \ddagger \S$ \\
\hline PE & $0.50 \pm 0.07$ & $1.42 \pm 0.11 \dagger$ & $0.82 \pm 0.01 t \ddagger$ & $0.67 \pm 0.03+\ddagger \S$ \\
\hline PG & $0.24 \pm 0.01$ & $0.72 \pm 0.003 \dagger$ & $0.60 \pm 0.08 \dagger$ & $0.11 \pm 0.01 \dagger \mp \S$ \\
\hline PA & $0.01 \pm 0.001$ & $0.01 \pm 0.002$ & $0.12 \pm 0.02 t \ddagger$ & $0.05 \pm 0.002 \dagger \ddagger \S$ \\
\hline DSPC & $1.68 \pm 0.08$ & $4.62 \pm 0.11 \dagger$ & $4.52 \pm 0.43 \dagger$ & $2.12 \pm 0.06+\$ \S$ \\
\hline USPC & $0.84 \pm 0.07$ & $2.38 \pm 0.15 \dagger$ & $2.41 \pm 0.17 \dagger$ & $1.34 \pm 0.05 \dagger+\S$ \\
\hline Total PL & $3.43 \pm 0.11$ & $9.46 \pm 0.23 \dagger$ & $9.56 \pm 0.78 \dagger$ & $4.80 \pm 0.12 \dagger \uparrow \S$ \\
\hline
\end{tabular}

* Values are nmol substrate incorporated $/ 4 \mathrm{~h} / 10^{6}$ cells (mean $\pm \mathrm{SEM}$ ) for three experiments with triplicate flasks per experiment. In these experiments, $0.3-0.7 \times 10^{6}$ cells from neonates $(6-8 \mathrm{~d}$ old $)$ and $0.8-1.0 \times 10^{6}$ cells from adults were used per flask. LPC, lysophosphatidylcholine; SP, sphingomyelin; PI, phosphatidylinositol; PL, phospholipid.

$\dagger$ Indicates a statistically significant difference at $p<0.05$ from the value of $\left[\mathrm{U}-{ }^{14} \mathrm{C}\right]$ glucose incorporation in the neonate

$¥$ Indicates a statistically significant difference at $p<0.05$ from the value of $\left[\mathrm{U}_{-}{ }^{14} \mathrm{C}\right] \mathrm{Clucose}$ incorporation in the adult.

$\S$ Indicates a statistically significant difference at $p<0.05$ from the value of $\left[3-{ }^{14} \mathrm{C}\right]$ acetoacetate incorporation in the neonate.

greater than $70 \%$ of the total radioactivity found in phospholipids was accounted for by PC. Furthermore, ${ }^{14} \mathrm{C}$-labeled DSPC represented approximately two thirds of the label incorporated into $\mathrm{PC}$. The predominant incorporation of ${ }^{14} \mathrm{C}$-radioactivity from substrates such as acetate and palmitate into PC $(56-78 \%$ of phospholipids) and DSPC (71-76\% of total PC) has also been observed for type II cells of adult rats (25-28). The present results suggest that neonatal type II cells are capable of incorporating various substrates into DSPC as the predominant phospholipid. Coincided with the ${ }^{14} \mathrm{C}$-label incorporation pattern, noenatal type II cells exhibited a characteristic phospholipid profile in that PC accounted for $67 \%$ of phospholipids and DSPC $70 \%$ of total PC (Table 2). These percentages are similar to those reported for adult $(3,20,29)$ and neonatal type II cells $(21)$.

Phenotypic alterations in metabolic activity of adult type II cells have been documented. For example, the purity, DNA, and lamellar inclusion body content of the cells decreased with increasing time (days) in culture (3). More importantly, the capacity to incorporate substrate into DSPC maintained at a constant rate for the first $2 \mathrm{~d}$ in culture but began to decline thereafter (25). The present study showed that neonatal type II cells were metabolically stable as indicated by the unchanged rate of [U${ }^{14} \mathrm{C}$ ]glucose incorporation into phospholipids during the first $3 \mathrm{~d}$ in culture. However, on d 4 not only did the rate of the incorporation into total phospholipids reduce by about $30 \%$, but the distribution of ${ }^{14} \mathrm{C}$-label into DSPC was also decreased (Table 3). These findings stress the importance of selecting a period of phenotypic stability for metabolic study in type II cells.
The subsequent experiments to compare the metabolic responses to substrates by neonatal and adult type II cells were therefore conducted with the cells maintained in culture for 24 h. Under the experimental conditions, glucose was incorporated more rapidly than acetoacetate into phospholipids by the adult cells. Conversely, ketone body was incorporated into phospholipids by the neonatal cells to a greater extent than glucose. It should be stressed that the rates of ${ }^{14} \mathrm{C}$-labeled substrate incorporation into phospholipids were estimated from exogenous precursor concentrations without taking into consideration endogenously available substrate pools. However, because of the negligible contribution by the endogenous sources, the rates measured in our study are likely to reflect the maximum capacities for utilizing acetoacetate and glucose by developing and mature rats. The rates of substrate incorporation presented in Table 5, therefore, suggest that acetoacetate is preferred over glucose as a precursor for DSPC in surfactant producing type II pneumocytes of the neonatal rats. They further support the earlier speculation that ketone bodies (acetoacetate and $\beta$-hydroxybutyrate) may play important roles in the biosynthesis of pulmonary surfactant $(12,17,30)$.

The reasons for the differential utilization of substrates by the neonatal and adult cells are not known. It is generally believed that a flux of metabolic pathway is regulated by substrate availability, enzyme activity, and hormone action. There are marked changes in the availability of metabolic fuel and lipid precursors during the neonatal stage. A 3- to 4-fold increase in plasma level 
of ketone bodies, accompanied by a low level of glucose, is commonly seen in human and rat neonates $(9,10)$, probably resulting from high fat and low carbohydrate content of milk (8). Due in part to these changes, newborns are adapted to utilize ketone bodies as a primary substrate for phospholipid synthesis by the lung $(12,30)$. The rapid rates of ketone incorporation into lung lipids (31) and surfactant lipids (17) most likely stem from an enhanced pathway involving acetoacetyl CoA synthetase and acetoacetyl $\mathrm{CoA}$ thiolase for the production of acetyl CoA from acetoacetate as evidenced by the markedly increased activities of the two enzymes in neonatal lungs (32). Additional support for this mechanism comes from an earlier study showing that, unlike glucose incorporation into lipid, which is dependent mainly on ATP-citrate lyase-mediated pathway, the rate of lipid synthesis from acetoacetate is not affected by $(-)$ hydroxycitrate, a potent inhibitor of ATP-citrate lyase (33). It may be speculated that the changes in the activities of the lipogenic and ketone utilizing enzymes noted in the whole lung must also occur in the type II pneumocytes. Thus, the accelerated rate of acetoacetate incorporation into phospholipids, particularly DSPC, by the neonatal type II cells may be attributed not solely to the increased availability of ketone bodies, but also to the stimulated acetoacetyl CoA synthetase pathway.

The mechanisms underlying the lower rate of glucose incorporation into phospholipids by the neonatal than by the adult type II cells are also obscure. Aside from substrate availability and enzyme activation and deactivation, phospholipid synthesis is subjected to regulation at a hormonal level (7). As a hormone responsive organ (34), the development of the lung and its lipid metabolism are known to be mediated by a variety of hormones (7). Hormones such as glucocorticoids, thyroid hormone, and estrogen have been shown to accelerate lung maturation and to increase surfactant in fetuses $(7,35)$. The importance of insulin in surfactant metabolism has been demonstrated. Glucose incorporation into $\mathrm{PC}$ was depressed in the perfused lung and type II cells of adult diabetic rats due to insulin deficiency $(29,36)$. Such an impairment was corrected by insulin treatment $(29,36)$. The response to insulin by fetal lungs is rather different. Insulin at low concentration $(10-25 \mu \mathrm{U} / \mathrm{mL})$ was stimulatory and at high concentration $(100-400 \mu \mathrm{U} / \mathrm{mL})$ inhibitory to PC synthesis in organotypic culture of fetal type II cells (37). As shown in this study, neonatal rats are also responsive to insulin. Exogenous insulin stimulated the rate of glucose utilization for PC synthesis in a dose-dependent manner by neonatal type II cells (Table 4). Although insulin enhances glucose uptake by adult type II cells (38) and perfused lung (39), it remains to be determined whether the increased rate of glucose incorporation into PC by insulin in the neonates is mediated by insulin receptor-enhanced glucose transport mechanism. Nevertheless, it is important to note that in rats insulin levels drop precipitously after birth and are thereafter maintained at $25-40 \mu \mathrm{U} / \mathrm{mL}$ throughout the suckling period, compared with $>80 \mu \mathrm{U} / \mathrm{mL}$ for adult rats (9). The insulin insufficiency together with low level of glucose may be responsible for the shift to the preferential incorporation of ketone body over glucose into phospholipids observed in this study.

Acknowledgments. The author thanks Shaw-Mei Yeh for technical assistance and Nancy Hopkins for typing the manuscript. The author is particularly thankful to Dr. Harold Edwards for his expert assistance in electron microscopic work.

\section{REFERENCES}

1. Clements JA 1977 Function of the alveolar lining. Am Rev Respir Dis 115:6771

2. Farrell PM, Avery ME 1975 Hyaline membrane disease. Am Rev Respir Dis 112:657-688

3. Mason RJ, Dobbs LG, Greenleaf RD, Williams MC 1977 Alveolar type II cells. Fed Proc 36:2697-2702
4. Van Golde LMG 1985 Synthesis of surfactant lipids in the adult lung. Annu Rev Physiol 47:765-774

5. Kikkawa Y, Yoneda K 1974 The type II epithelial cell of the lung. I. Method of isolation. Lab Invest 30:76-84

6. Van Golde LMG 1985 Synthesis of surfactant lipids in the adult and fetal lung: pathway and regulatory aspects. Eur J Respir Dis 142:19-28

7. Rooney SA 1985 The surfactant system and lung phospholipid biochemistry. Am Rev Respir Dis 131:436-460

8. Dymsza HA, Czajka DM, Miller SA 1964 Influence of artificial diet on weight gain and body composition of the neonatal rat. J Nutr 84:100-106

9. Yeh Y-Y, Zee P 1976 Insulin, a possible regulator of ketosis in newborn and suckling rats. Pediatr Res 10:192-197

10. Persson B, Gentz J 1966 The pattern of blood lipids, glycerol and ketone bodies during the neonatal period, infancy and childhood. Acta Paediatr Scand 55:353-362

11. Webber RJ, Edmond J 1979 The in vivo utilization of acetoacetate, D- $(-) 3$ hydroxybutyrate, and glucose for lipid synthesis in brain in the 18-day-old rat. Evidence for an acetyl-CoA bypass for sterol synthesis. J Biol Chem 254:3912-3920

12. Yeh Y-Y, Sheehan PM 1985 Preferential utilization of ketone bodies in the brain and lung of newborn rats. Fed Proc 44:2352-2358

13. Mason RJ, Williams MC, Greenleaf RD, Clements JA 1977 Isolation and properties of type II alveolar cells from rat lung. Am Rev Respir Dis 115:1015-1026

14. Post M, Schuurmans E, Batenburg JJ, Van Golde LMG 1983 Mechanisms involved in the synthesis of disaturated phosphatidylcholine by alveolar type II cells isolated from adult rat lung. Biochim Biophys Acta 750:68-77

15. Folch J, Lees M, Sloan-Stanley GH 1957 A simple method for the isolation and purification of total lipids from animal tissues. J Biol Chem 226:497509

16. Gilfillan AM, Chu AJ, Smart DA, Rooney SA 1983 Single plate separation of lung phospholipids including disaturated phosphatidylcholine. J Lipid Res 24:1651-1656

17. Sheehan PM, Yeh Y-Y 1985 Pulmonary surfactant lipid synthesis from ketone bodies, lactate and glucose in newborn rats. Lipids 20:835-841

18. Bartlett GR 1959 Phosphorus assay in column chromatography. J Biol Chem 234:466-468

19. Krebs HA, Eggleston LV 1945 Metabolism of acetoacetate in animal tissues. Biochem J 39:408-419

20. Dobbs LG, Geppert G, Greenleaf RD, Williams MC, Mason RJ 1980 Metabolic properties and ultra-structure of alveolar type II cells isolated with elastase. Biochim Biophys Acta 618:510-523

21. Saito K, Lwebuga-Mukasa J, Barrett C, Light D, Warshaw JB 1985 Characteristics of primary isolates of alveolar type II cells from neonatal rats. Exp Lung Res 8:213-225

22. Kennedy KA, Crouch LS, Warshaw JB 1989 Effect of hyperoxia on antioxidants in neonatal rat type II cells in vitro and in vivo. Pediatr Res 26:400403

23. Richards RJ, Davies N, Atkins J, Oreffo VIC 1987 Isolation, biochemical characterization, and culture of lung type II cells of the rat. Lung 165:143158

24. Batenburg JJ, Otto-Verberne CJM, Ten Have-Opbroek AAW, Klazinga W 1988 Isolation of alveolar type II cells from fetal rat lung by differential adherence in monolayer culture. Biochim Biophys Acta 960:441-453

25. Smith FB, Kikkawa Y, Diglio CA, Dalen RC 1980 The type II epithelial cells of the lung. VI. Incorporation of ${ }^{3} \mathrm{H}$-choline and ${ }^{3} \mathrm{H}$-palmitate into lipids of cultured type II cells. Lab Invest 42:296-301

26. Dobbs LG, Williams MC, Brandt AE 1985 Changes in biochemical characteristics and pattern of lectin binding of alveolar type II cells with time in culture. Biochim Biophys Acta 846:155-166

27. Mason RJ, Nellenbogen J 1984 Synthesis of saturated phsophatidylcholine and phosphatidylglycerol by freshly isolated rat alveolar type II cells. Biochim Biophys Acta 794:392-402

28. Batenburg JJ, Longmore WJ, Van Golde LMG 1978 The synthesis of phosphatidylcholine by adult rat lung alveolar type II epithelial cells in primary culture. Biochim Biophys Acta 529:160-170

29. Uhal BD, Longmore WJ 1986 Altered phospholipid biosynthesis in type II pneumocytes isolated from streptozotocin-diabetic rats. Biochim Biophys Acta 878:266-272

30. Patterson CE, Rhoades RA 1989 Substrate utilization in the perinatal lung. Am J Physiol 257:L318-L330

31. Sheehan PM, Yeh Y-Y 1983 Lung lipid synthesis from acetoacetate and glucose in developing rats in vitro. Lipids 18:295-301

32. Yeh Y-Y 1982 Biosynthesis of lung lipids from acetoacetate and glucose in the developing rat in vivo. Int $\mathrm{J}$ Biochem 14:81-86

33. Sheehan PM, Yeh Y-Y 1984 Pathways of acetyl CoA production for lipogenesis from acetoacetate, $\beta$-hydroxybutyrate, pyruvate and glucose in neonatal rat lung. Lipids 19:103-108 
34. Stubbs WA, Alberti KGMM 1980 The lung, whole-body metabolism and disease. In: Whelan J (ed) Metabolic Activity of the Lung. Excerpta Medica, Amsterdam, pp 351-372

35. Post M, Barsoumian A, Smith BT 1986 The cellular mechanism of glucocorticoid acceleration of fetal lung maturation. J Biol Chem 261:2179-2184

36. Moxley MA, Longmore WJ 1977 Effect of experimental diabetes and insulin on lipid metabolism in the isolated perfused rat lung. Biochim Biophys Acta 488:218-224

37. Engle MJ, Langan SM, Sanders RL 1983 Effects of insulin and hyperglycemia on surfactant phospholipid synthesis in organotypic type II cells. Biochim Biophys Acta 753:6-13

38. Sugahara K, Friedenberg GR, Mason RJ 1984 Insulin binding and effects on glucose and transepithelial transport by alveolar type Il cells. Am J Physiol 247:C472-C477

39. Fricke RF, Longmore WJ 1979 Effects of insulin and diabetes on 2-deoxy-dglucose uptake by the isolated perfused rat lung. J Biol Chem 254:50925098

\section{Announcement}

\section{Annual Meeting of the European Society for Pediatric Research 1991}

The European Society for Pediatric Research (ESPR) will hold its next meeting in Zürich, Switzerland, September 1-4, 1991. The European Society of Pediatric Allergy and Clinical Immunology and the European Society of Magnetic Resonance in Neuropediatrics will join the ESPR. Satellite postgraduate courses and a symposium will be organized by these two societies on September 1 and September 5 .

The main topics of the ESPR meeting are: therapeutic interventions in immune-mediated diseases, connective tissue, energy metabolism, and circulation of the neonatal brain.

For information, contact: Gabriel Duc, University Hospital of Zürich, Frauenklinikstrasse 10, ZH-8091 Zürich, Tel. + 41125553 40, Telefax + 4112554442 . 